\title{
Energy and Productivity Yield Assessment of a Traditional Furnace for Noncentrifugal Brown Sugar (Panela) Production
}

\author{
Luis F. Gutiérrez-Mosquera $\mathbb{D}^{1},{ }^{1}$ Sebastián Arias-Giraldo ${ }^{1 D},^{2}$ \\ and Adela M. Ceballos-Peñaloza $\mathbb{i D}^{2}$ \\ ${ }^{1}$ Department of Engineering, Food and Agribusiness Research Group, Universidad de Caldas, Calle 65 No. 26-10, \\ Manizales, Colombia \\ ${ }^{2}$ Food and Agribusiness Research Group, Universidad de Caldas, Calle 65 No. 26-10, Manizales, Colombia
}

Correspondence should be addressed to Luis F. Gutiérrez-Mosquera; fernando.gutierrez@ucaldas.edu.co

Received 7 February 2018; Revised 15 May 2018; Accepted 5 June 2018; Published 5 July 2018

Academic Editor: Junwu Wang

Copyright (c) 2018 Luis F. Gutiérrez-Mosquera et al. This is an open access article distributed under the Creative Commons Attribution License, which permits unrestricted use, distribution, and reproduction in any medium, provided the original work is properly cited.

\begin{abstract}
Noncentrifugal brown sugar (called panela in Colombia) is a natural sweetener obtained from the extraction, purification, and concentration of sugarcane juices. In this work, energy and productivity yield of a traditional furnace for panela production were evaluated, considering five performance indices. Experimental productions were developed in a pilot plant facility, analyzing furnace gas emissions of furnace and bagasse properties. Mass, energy, and exergy balances were performed. The following indices were obtained from the experimental runs: energy efficiency $12.726 \pm 1.091 \%$, exergy efficiency $9.013 \pm 0.710 \%$, energy losses

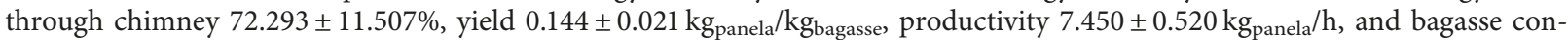

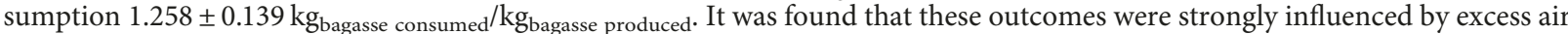
and gas circulation velocity through the furnace, which affects the combustion rate and heat transfer between the gases and the juices. Finally, it was concluded that the traditional scheme is inefficient and requires various critical operational adjustments, such as combustion chamber, chimney draft control, and heat exchangers design.
\end{abstract}

\section{Introduction}

Noncentrifugal brown sugar, called jaggery in India, panela in Colombia, and rapadura in Brazil, is a natural food obtained by extraction and concentration of sugarcane juices (Saccharum officinarum). Worldwide, it is used as a sweetener or as a ready-to-consumer product, highly valued for its appreciable energy supply and contribution to the food security. The main component of panela is sucrose, although glucose, fructose; vitamins A, C, D, E, and B; and minerals such as calcium, iron, potassium and zinc also stand out $[1,2]$. In the world, Colombia has the highest consumption of noncentrifugal brown sugar per capita $(22 \mathrm{~kg} /$ year $)$ and is the second highest international producer with a $12 \%$ global market share. Approximately 350,000 families work in the Colombian noncentrifugal brown sugar sector, which produces more than 1,330,000 tons of panela annually in 236 municipalities $[3,4]$.
The production of panela from sugarcane is performed in locations called sugar mills (trapiche in Spanish), through ancestral and traditional methods. To obtain noncentrifugal brown sugar, the sugarcane juices are extracted using a mill, to be subsequently filtered, purified, and clarified. When the contaminants have been removed, it proceeds to evaporation and concentration of sugarcane juices using a series of metal receptacles, heat exchangers, or pans. The residual bagasse of the milling is used as solid fuel material. The determination of appropriate heating time is made empirically. Finally, the concentrate taken from the pans is beaten and molded, and then the noncentrifugal brown sugar is packed as the final product [5].

The technological system, in which thermal energy transfer is carried out between the combustion gases and the juices, in order to reach dissolved solids concentration between $88-94^{\circ}$ Brix, is called traditional furnace (Figure 1). The traditional furnace is composed of the bagasse feed zone, 


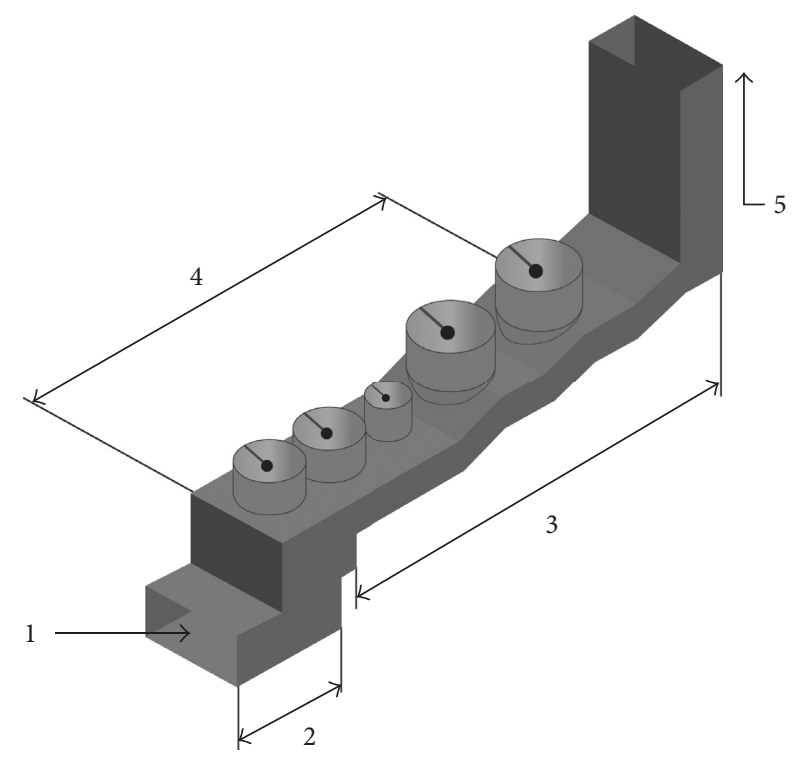

Figure 1: Traditional furnace for panela production: 1. Bagasse feed zone. 2. Combustion chamber. 3. Gas duct. 4. Heat exchangers (pans). 5. Chimney.

combustion chamber, gases circulation tunnel, heat exchangers, and chimney.

High energy loss in the traditional furnace is the principal disadvantage of this technology. Additionally, the overall productivity of the process is diminished by factors like exhaust gases leaving the chimney, poor combustion, and the low heat transfer through the system. This feature is also carrying environmental problems such as burning of tires, plastics, and wood [6]. In order to enhance the energy efficiency of the traditional furnace, some research projects have been performed: sugarcane concentration system using steam, multiple effect evaporators, and different CIMPA type multiefficient combustion chamber designs can be found in the scientific papers.

In order to evaluate the process used in Colombia for transforming sugarcane into panela, and propose a future intervention to strengthen of the most critical points in the technological system that directly affect the energy indices and productivity yield of the furnaces, the goal of this work was the energy and productivity yield assessment of a traditional furnace employed in the noncentrifugal brown sugar production, considering the following six indices: energy efficiency (\%), exergy efficiency (\%), energy loss through chimney (\%), yield $\left(\mathrm{kg}_{\text {panela/kgbagasse }}\right)$, productivity $\left(\mathrm{kg}_{\text {panela/ }} \mathrm{h}\right)$, and bagasse consumption ( $\left.\mathrm{kg}_{\text {bagasse consumed/kgbagasse produced }}\right)$.

\section{Materials and Methods}

Experimental runs for panela productions were developed in a traditional furnace, placed in the municipality of Supía, Caldas, Colombia. The raw materials used were the most uniform possible, acquiring cane sugar juices, bagasse, and clarifying agent with a sole provider. Five noncentrifugal brown sugar productions were realized. In each one of them, the end product (panela) was obtained at $120^{\circ} \mathrm{C}$ of temperature and a dissolved solids concentration equal to $90^{\circ}$ Brix. Sugarcane juices used in the process had an average dissolved solids concentration between 17 and $18^{\circ}$ Brix [7]. The clarification process of cane juices was performed using mucilage from cadillo plant (Triumfetta láppulal) like clarifying agent, added during the clarification process at $70^{\circ} \mathrm{C}$ of temperature [8]. In order to reach the stable state during the experimental runs, the traditional furnace was operated initially heating arbitrary volumes of water for one hour, or until the temperature of the chimney gases gotten constant values.

The following parameters were controlled and registered in each treatment: bagasse consumption rate, sugarcane juice quantity, clarifying extract dosage (flocculant), collected mud (suspended matter obtained during the clarification process), work time, dissolved solids concentration in juice and panela (ATAGO PAL-3 Digital Refractometer), temperature for the addition of mucilage from cadillo, temperature at the final point of panela (Type $\mathrm{K}$ Thermocouple, associated with a ThermoWorks Microtherma 2), room temperature, and relative humidity (EXTECH Thermo-hygrometer).

An evaluation of gases emissions form chimney was executed using the methodologies established by EPA [9], taking the following information: temperature and velocity of fluid, humidity, excess air, and concentration of carbon monoxide (CO), carbon dioxide $\left(\mathrm{CO}_{2}\right)$, oxygen $\left(\mathrm{O}_{2}\right)$, nitrogen $\left(\mathrm{N}_{2}\right)$, sulfur dioxide $\left(\mathrm{SO}_{2}\right)$, and nitrogen dioxide $\left(\mathrm{NO}_{2}\right)$. A combustion gas analyzer (E-Instruments 5500) and an isokinetic sampling console (ES-Environmental Supply Company C-5000) were used for measuring these variables. Moreover, samples of bagasse from each production were collected. They were analyzed in the Fuels and Combustion Laboratory of the Universidad del Valle, located in Cali, Colombia, in order to determine the moisture, carbon, hydrogen, nitrogen, sulfur, oxygen, and ash content by element analysis and the lower calorific value $(\mathrm{MJ} / \mathrm{kg})$ through proximate analysis.

2.1. Mass Balance. Assessment of the traditional furnace was performed using the outcomes obtained from five experimental run productions. Thermal, physical, and rheological properties of sugarcane and panela were taken of Arias et al. [10]. Mass, energy, and exergy balance were solved using Microsoft Excel 2013 and Matlab R2013a software. The mass balance of the traditional furnace for manufacturing panela was adapted from the methodology described by Velásquez et al. [6] and Shiralkar et al. [11], supposing mass balance without chemical reaction and steady state conditions. Figure 2 shows the material flows involved in the process. Global mass balance is described by (1). Equations (2)-(4) were used for the combustion chamber, gas duct, and the chimney (Figure 1).

$$
\begin{aligned}
& m_{\mathrm{bs}}+m_{\mathrm{ab}}+m_{\mathrm{as}}+m_{\mathrm{aa}}+m_{\mathrm{jc}}+m_{\mathrm{fl}} \\
& =m_{\mathrm{gs}}+m_{\mathrm{at}}+m_{\mathrm{mp}}+m_{\mathrm{r}}+m_{\mathrm{p}}+m_{\mathrm{ae}}+m_{\mathrm{ch}}, \\
& m_{\mathrm{bs}}+m_{\mathrm{ab}}+m_{\mathrm{as}}+m_{\mathrm{aa}}=m_{\mathrm{gs}}+m_{\mathrm{at}}+m_{\mathrm{mp}}+m_{\mathrm{r}},
\end{aligned}
$$




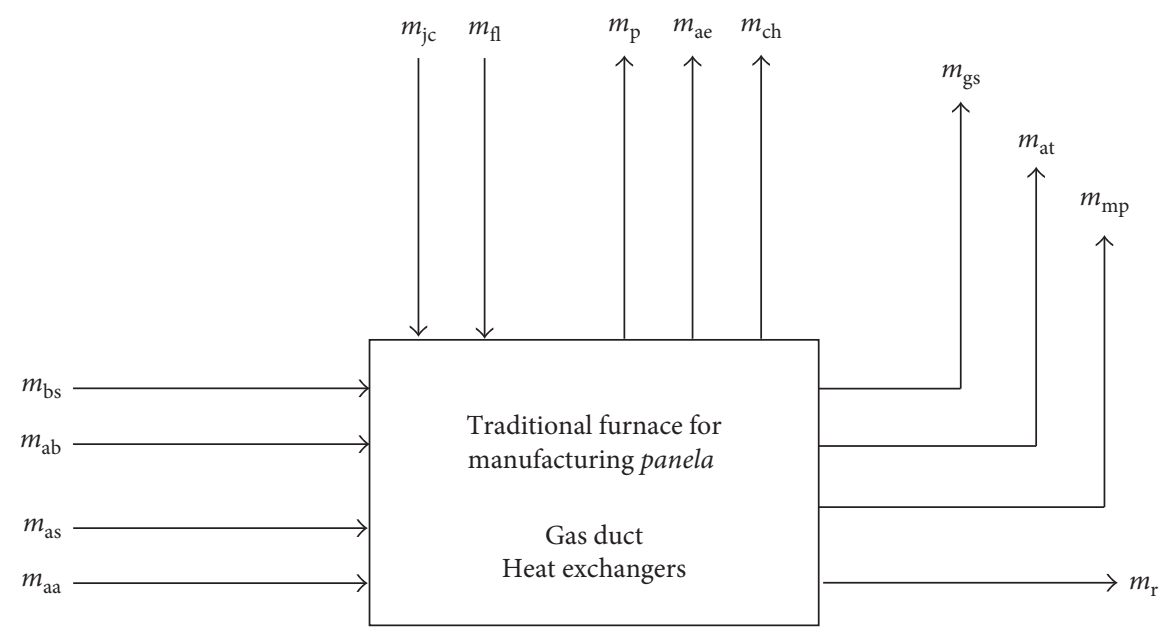

FIgURE 2: Traditional furnace mass balance, mass in kg. $m_{\mathrm{bs}}$ : dry bagasse (husk), $m_{\mathrm{ab}}$ : quantity of water in the bagasse (moisture), $m_{\mathrm{as}}$ : dry air for combustion, $m_{\mathrm{aa}}$ : water inlet with the air, $m_{\mathrm{jc}}$ : mass of sugarcane juice, $m_{\mathrm{f}}$ : flocculant extract, $m_{\mathrm{p}}$ : noncentrifugal brown sugar ( $\left.p a n e l a\right)$ obtained, $m_{\mathrm{ae}}$ : water evaporated during the concentration, $m_{\mathrm{ch}}$ : mud removed from clarification, $m_{\mathrm{gs}}$ : dry combustion gases leaving through chimney, $m_{\mathrm{at}}$ : steam that accompanies the gases through the chimney, $m_{\mathrm{mp}}$ : particulate material, and $m_{\mathrm{r}}$ : unburned cinder collected from the traditional furnace floor.

$$
\begin{aligned}
& m_{\mathrm{bs}}=m_{\mathrm{bh}} *(1-w), \\
& m_{\mathrm{ab}}=m_{\mathrm{bh}} *(w) .
\end{aligned}
$$

Knowing the excess air of combustion for each trial, and considering the elemental composition of the dry bagasse, the air supply into the traditional furnace was estimated. The initial oxygen content in the bagasse and the stoichiometry of the reaction were taken into account to quantify the theoretical oxygen required for the complete combustion of $\mathrm{C}, \mathrm{H}$, and $\mathrm{S}$. With the molar composition for the standard air, the oxygen and nitrogen mass inlet to combustion chamber were determined as dry air. The air absolute humidity, in $\mathrm{kg}_{\mathrm{H}_{2} \mathrm{O}} / \mathrm{kg}_{\text {as }}$, was calculated according to Geankoplis [12], and mass of water in the air intake was determined. Exhaust gases volumetric flow, given in $\mathrm{m}^{3} / \mathrm{s}$, was quantified as the product between the chimney gases velocity and the cross-sectional area of the duct at the sampling point. On the other hand, the total mass of chimney gases was calculated knowing their density in $\mathrm{kg} / \mathrm{m}^{3}$. The methodology proposed by Seader et al. [13] was used for density estimation. The quantity of dry exhaust gases and the humidity leaving the chimney were determined using the data provided by the emissions analysis, through (5) and (6). At the end of each production, the unburned residue that was accumulated into the gas duct was collected in order to quantify its mass.

$$
\begin{aligned}
& m_{\mathrm{at}}=m_{\mathrm{gh}} * w_{\mathrm{gh}}, \\
& m_{\mathrm{gs}}=m_{\mathrm{gh}}-m_{\mathrm{at}} .
\end{aligned}
$$

For determining evaporated water mass in the concentration process, (7) was solved. The collected mud during the clarification of each production was decanted for one hour and later weighed. The solid material $\left(m_{\mathrm{sch}}\right)$ and the remnant juice in the mud $\left(m_{\mathrm{lch}}\right)$ were split, according to $(8)$.
The panela obtained from each experimental runs was weighed, packaged, and stored.

$$
\begin{gathered}
m_{\mathrm{jc}}+m_{\mathrm{fl}}=m_{\mathrm{p}}+m_{\mathrm{ch}}+m_{\mathrm{ae}}, \\
m_{\mathrm{ch}}=m_{\mathrm{sch}}+m_{\mathrm{lch}} .
\end{gathered}
$$

2.2. Energy and Exergy Balances. Energy balance for the traditional furnace was solved following partially the model presented by Velásquez et al. [6], keeping steady state conditions (according to Figure 3 ). The reference temperature and pressure were $0^{\circ} \mathrm{C}$ and 1 atm, respectively. Equation (9) develops global energy balance for the process:

$$
E_{1}+E_{2}+E_{3}+E_{4}+E_{5}=E_{6}+E_{7}+E_{8}+E_{9}+E_{10} .
$$

Using the lower calorific value of the bagasse, expressed in $\mathrm{MJ} / \mathrm{kg}$, the energy quantity associated with this material was calculated. The enthalpy of the ambient humid air $\left(\mathrm{kJ} / \mathrm{kg}_{\mathrm{as}}\right)$ was found according to Geankoplis [12].

$$
\begin{aligned}
& E_{1}=\left(m_{\mathrm{bs}}+m_{\mathrm{ab}}-m_{\mathrm{r}}-m_{\mathrm{mp}}\right) * \mathrm{PCN}, \\
& E_{2}=m_{\mathrm{as}} * H_{\mathrm{Y}} .
\end{aligned}
$$

For the sugarcane juice, solid contaminants, flocculant extract, and panela, the following mathematical expressions were used:

$$
\begin{aligned}
& E_{3}=\left(m_{\mathrm{jc}}-m_{\mathrm{sch}}\right) * C p_{\mathrm{jc}} * T_{\mathrm{jc}} \\
& E_{4}=m_{\mathrm{sch}} * C p_{\mathrm{sch}} * T_{\mathrm{sc}} \\
& E_{5}=m_{\mathrm{fl}} * C p_{\mathrm{fl}} * T_{\mathrm{fl}} \\
& E_{6}=m_{p} * C p_{p} * T_{\text {point }} .
\end{aligned}
$$

$120^{\circ} \mathrm{C}$ was established like the final temperature at which noncentrifugal brown sugar was obtained $\left(T_{\text {point }}=120^{\circ} \mathrm{C}\right)$. 


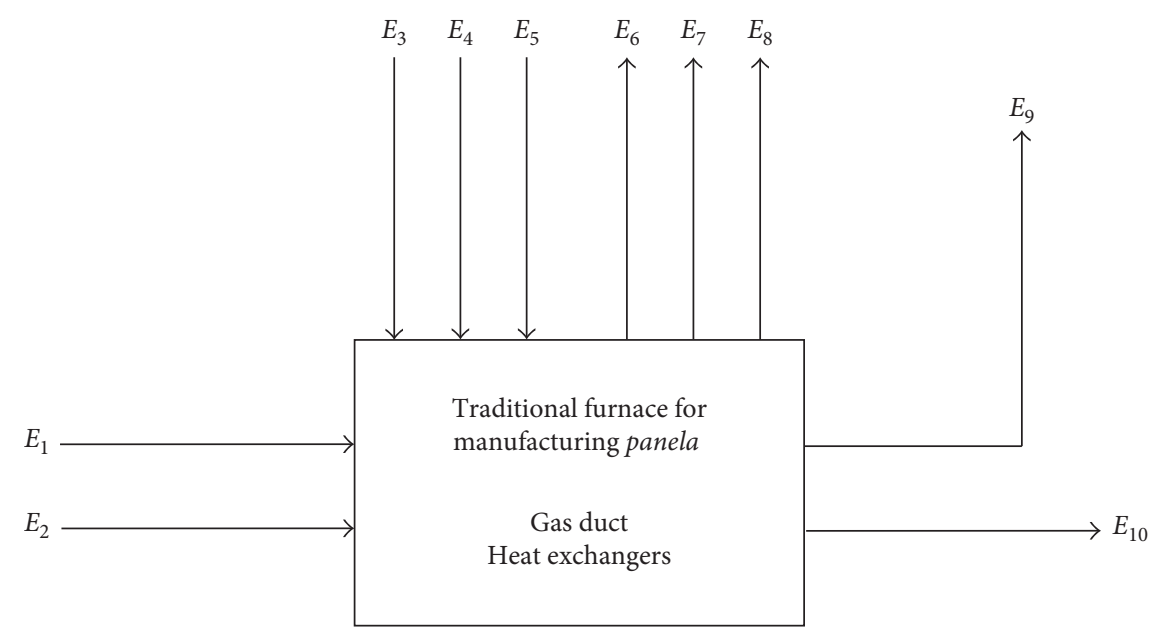

FiguRE 3: Energy balance in traditional furnace for making panela, energy in kJ. $E_{1}$ : bagasse, $E_{2}$ : air, $E_{3}$ : sugarcane juice, $E_{4}$ : solid contaminants in the sugarcane juice, $E_{5}$ : flocculant extract, $E_{6}$ : noncentrifugal brown sugar produced, $E_{7}$ : mud, $E_{8}$ : steam released during the evaporation, $E_{9}$ : chimney gases, and $E_{10}$ : other energy losses.

The solid contaminants specific heat (flocculant) was assumed as $2.2 \mathrm{~kJ} / \mathrm{kg} .{ }^{\circ} \mathrm{C}$. This property was calculated as a mix of water and carbohydrates. According to Montoya and Giraldo [14], the mud-specific heat was taken as $2.8 \mathrm{~kJ} / \mathrm{kg} .{ }^{\circ} \mathrm{C}$. The steam energy and energy of chimney gases were given by (13) and (14). For determining the thermodynamic properties of evaporated water and chimney gases, the SoaveRedlich-Kwong (SRK) model was used [13]. The roots of the equations were found with Matlab software version R2013a. For the case of the chimney gases, the rules of mixing proposed by Seader et al. [13] were used to estimate specific volume, molar enthalpy, and molar entropy. The $k_{i j}$ value was predicted according to Coutinho et al. [15].

$$
\begin{aligned}
& E_{7}=m_{\mathrm{ch}} * 2.8 * T_{\mathrm{cl}}, \\
& E_{8}=m_{\mathrm{ae}} *\left(\frac{h_{\mathrm{mae}}}{M_{\mathrm{ae}}}\right), \\
& E_{9}=m_{\mathrm{gh}} *\left(\frac{h_{\mathrm{mgh}}}{M_{\mathrm{gh}}}\right) .
\end{aligned}
$$

Exergy balance, according to Velásquez et al. [16], was developed for combustion chamber, gas duct, and chimney in steady state. In addition, exergy analysis involves the pans system where the cane juice, evaporated water, and panela streams were considered (see Figure 4 and (15)).

$$
\begin{aligned}
\mathrm{Ex}_{\mathrm{bh}}+\mathrm{Ex}_{\mathrm{jc}} & =\mathrm{Ex}_{\mathrm{gh}}+\mathrm{Ex}_{\mathrm{ae}}+\mathrm{Ex}_{\mathrm{p}}+\mathrm{Ex}_{\mathrm{dp}}, \\
\mathrm{Ex}_{\mathrm{ap}} & =\mathrm{Ex}_{\mathrm{ae}}+\mathrm{Ex}_{\mathrm{p}} .
\end{aligned}
$$

The physical exergy of chimney gases was calculated in order to establish their available energy, as shown in (17). The kinetic and potential exergy were neglected [17].

$$
\varphi=\left(h-h_{\mathrm{o}}\right)-\left[T_{\mathrm{o}} *\left(s-s_{\mathrm{o}}\right)\right] .
$$

Physical exergy for the air, the bagasse, and the raw juice were taken as zero, since both materials enter to the system at room temperature. Ashes exergy was neglected, because its low mass has a minimal level of energy. The air does not have chemical exergy, given that this substance forms part of the natural environment [16]. According to Kotas [18], bagasse chemical exergy $\left(\mathrm{Ex}_{\mathrm{Qbh}}\right)$ was given by the expression

$$
\begin{aligned}
\mathrm{Ex}_{\mathrm{bh}} & =m_{\mathrm{bh}} * \mathrm{Ex}_{\mathrm{Qbh}}, \\
\frac{\mathrm{Ex}_{\mathrm{Qbh}}}{\mathrm{PCN}} & =\frac{\left[1.0438+1.882\left(x_{\mathrm{H}} / x_{\mathrm{C}}\right)-0.2509\left(1+0.7256\left(x_{\mathrm{H}} / x_{\mathrm{C}}\right)\right)+0.0383\left(x_{\mathrm{N}} / x_{\mathrm{C}}\right)\right]}{1-0.3035\left(x_{\mathrm{O}} / x_{\mathrm{C}}\right)} .
\end{aligned}
$$

Velásquez et al. [16] reported a chemical exergy for the sucrose of $7.06 \mathrm{~kJ} / \mathrm{kg}$ and (20) to calculate the chemical exergy of sugarcane juice.

$$
\begin{aligned}
\mathrm{Ex}_{\mathrm{jc}}= & m_{\mathrm{jc}} * \mathrm{Ex}_{\mathrm{Qjc}}, \\
\operatorname{Ex}_{\mathrm{Qjc}}= & \left(x_{\mathrm{H}_{2} \mathrm{O}} * \mathrm{Ex}_{\mathrm{QH}_{2} \mathrm{O}}\right) \\
& +\left(x_{\text {sucrose }} * E x_{\text {Qsucrose }}\right) .
\end{aligned}
$$

Chimney gases exergy have both physical and chemical components. The physical availability is known by (17), while chemical exergy was calculated through [16]:

$$
\begin{aligned}
\mathrm{Ex}_{\mathrm{gh}} & =m_{\mathrm{gh}} *\left(\mathrm{Ex}_{\mathrm{Fgh}}+\mathrm{Ex}_{\mathrm{Qgh}}\right), \\
\mathrm{Ex}_{\mathrm{Qgh}} & =R * T_{\mathrm{o}} * \sum_{j=1}^{n}\left[\gamma_{j} * \ln \left(\frac{\gamma_{j}}{\gamma_{j}^{\text {ambient }}}\right)\right] .
\end{aligned}
$$




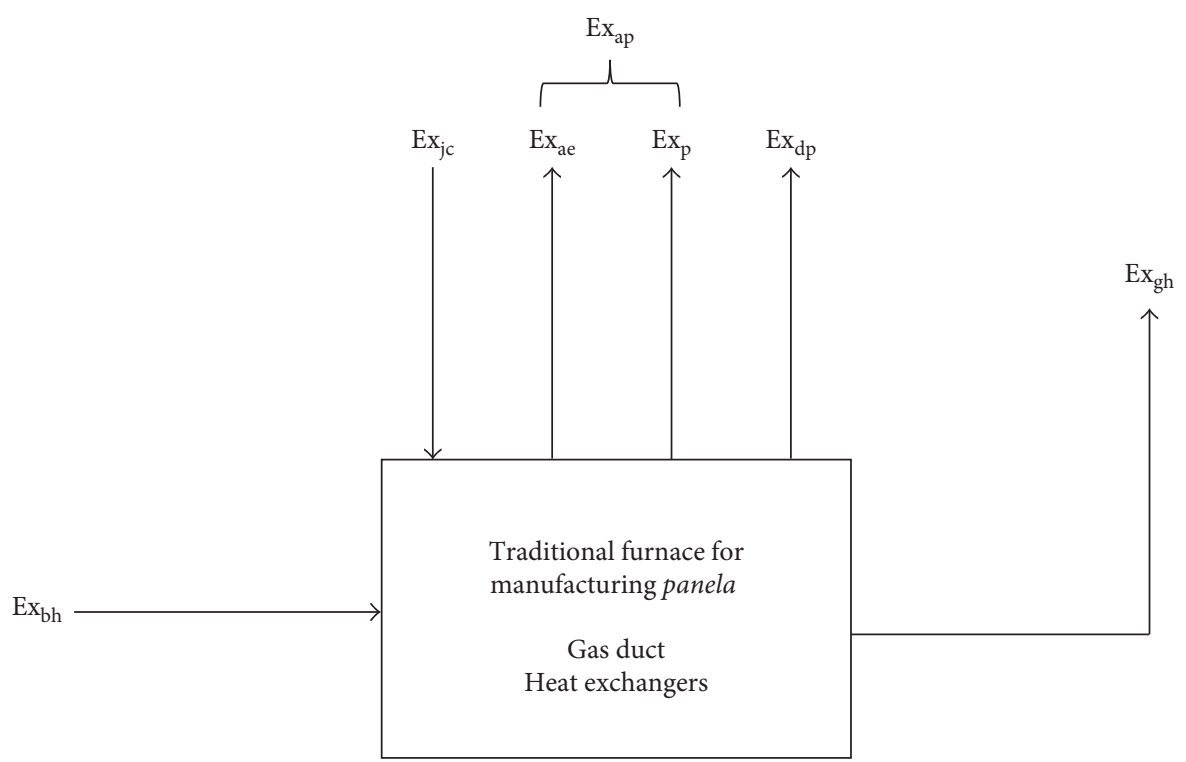

FIgURE 4: Exergy balance for the traditional furnace, exergy in $\mathrm{kJ}$. Humid bagasse $\left(\mathrm{Ex}_{\mathrm{bh}}\right)$, sugarcane juice $\left(\mathrm{Ex}_{\mathrm{jc}}\right)$, evaporated water $\left(\mathrm{Ex}_{\mathrm{ae}}\right)$, panela $\left(\mathrm{Ex}_{\mathrm{p}}\right)$, chimney gases $\left(\mathrm{Ex}_{\mathrm{gh}}\right)$, and exergy destruction $\left(\mathrm{Ex}_{\mathrm{dp}}\right) . \mathrm{Ex}_{\mathrm{ap}}$ represents the exergy harnessed and consumed during the operation and corresponds to the sum of $\mathrm{Ex}_{\mathrm{ae}}$ and $\mathrm{Ex}_{\mathrm{p}}$.

TABle 1: Performance indices used to assess the traditional furnace.

\begin{tabular}{lc}
\hline Performance indices & Equation \\
\hline Energy efficiency $(\%)$ & $\% e=\left[\left(E_{6}+E_{7}+E_{8}\right) / E_{1}\right] * 100$ \\
Exergy efficiency $(\%)$ & $\% e_{x}=\left[\left(E_{\mathrm{xae}}+E_{\mathrm{xp}}\right) /\left(E_{\mathrm{xbh}}+E_{\mathrm{xjc}}\right)\right] * 100$ \\
Energy loss through the chimney $(\%)$ & $\% n=\left(E_{9} / E_{1}\right) * 100$ \\
Yield $\left(\mathrm{kg}_{\text {panela }} / \mathrm{kg}_{\text {bagasse }}\right)$ & $R=\left(m_{\mathrm{p}} / m_{\mathrm{bh}}\right)$ \\
Productivity $\left(\mathrm{kg}_{\text {panela }} / \mathrm{h}\right)$ & $P=\left(m_{\mathrm{p}} / t_{\mathrm{production}}\right)$ \\
Bagasse consumption $\left(\mathrm{kg}_{\text {bagasse consumed }} / \mathrm{kg}_{\text {produced bagasse }}\right)$ & $B=\left(m_{\mathrm{bh}} / m_{\mathrm{bp}}\right)$ \\
\hline
\end{tabular}

To determine total exergy efficiency of the production process, water and panela exergy values may be determined. The physical and chemical exergies were obtained from Kotas [18].

$$
\begin{aligned}
\mathrm{Ex}_{\mathrm{ae}} & =m_{\mathrm{ae}} *\left(\mathrm{Ex}_{\mathrm{Fae}}+\mathrm{Ex}_{\mathrm{Qae}}\right), \\
\mathrm{Ex}_{\mathrm{Qae}} & =-R * T_{\mathrm{o}} * \ln \left(\gamma_{\mathrm{H}_{2} \mathrm{O}}^{\mathrm{ambient}}\right), \\
\mathrm{Ex}_{\mathrm{Fae}} & =\left(h_{\mathrm{ae}}-h_{\mathrm{o}}\right)-\left[T_{\mathrm{o}} *\left(s_{\mathrm{ae}}-s_{\mathrm{o}}\right)\right], \\
\mathrm{Ex}_{\mathrm{p}} & =m_{\mathrm{p}} *\left(\mathrm{Ex}_{\mathrm{Fp}}+\mathrm{Ex}_{\mathrm{Qp}}\right), \\
\mathrm{Ex}_{\mathrm{Qp}} & =\left(x_{\mathrm{H}_{2} \mathrm{O}} * \mathrm{Ex}_{\mathrm{QH}_{2} \mathrm{O}}\right)+\left(x_{\text {sucrose }} * \mathrm{Ex}_{\mathrm{Qsucrose}}\right), \\
\mathrm{Ex}_{\mathrm{Fp}} & =\mathrm{Cp}_{\mathrm{p}} *\left(T_{\text {point }}-T_{\mathrm{o}}\right)-\left[T_{\mathrm{o}} * \mathrm{Cp}_{\mathrm{p}} * \ln \left(\frac{T_{\text {point }}}{T_{\mathrm{o}}}\right)\right] .
\end{aligned}
$$

2.3. Performance Indices. The traditional furnace for manufacturing panela was analyzed considering the indices presented in Table 1, proposed by Velásquez et al. [6] and Velásquez et al. [16].

\section{Results and Discussion}

3.1. Sugarcane Bagasse Characterization. Table 2 shows the results of the elemental and proximate analyses of sugarcane bagasse. The bagasse characterization outcomes are similar to those reported by Shiralkar et al. [11]. Nevertheless, it is worth noting that bagasse composition depends on cane variety, soil conditions, and crop nutrition [5]. For this reason, and considering that the cane harvest was done in a single cut, some differences with respect to available information in the literature can be found. For example, the lower calorific values reported by Shiralkar et al. [11] were found between 15.20 and $16.40 \mathrm{MJ} / \mathrm{kg}$, determined for bagasse samples from different locations.

According to Sánchez et al. [19], in a fixed-bed combustion, gases composition and combustion rate can be optimized using bagasse with a moisture content between $10 \%$ and $30 \%$, as used in this work. Low water content in solid fuel drives an appropriate carbon into $\mathrm{CO}_{2}$ conversion, increasing the volatile compounds release rate and the material oxidation. In this way, the combustion efficiency can be increased in a range between $49 \%$ and $55 \%$, compared to the use of bagasse with humidity greater than $40 \%$. In addition, the combustion temperature is $16 \%$ higher [19]. 
TABLE 2: Elemental analysis of bagasse and determination of its lower calorific value (PCN).

\begin{tabular}{|c|c|c|c|c|c|c|}
\hline Property & Lot 01 & Lot 02 & Lot 03 & Lot 04 & Lot 05 & Mean* \\
\hline Total moisture (\%) & 16.96 & 12.72 & 16.58 & 14.24 & 14.39 & $14.98 \pm 1.77$ \\
\hline Ash (\%) & 4.51 & 7.20 & 3.60 & 3.08 & 3.36 & $4.35 \pm 1.68$ \\
\hline Carbon (\%) & 40.09 & 42.17 & 40.62 & 41.73 & 42.03 & $41.33 \pm 0.92$ \\
\hline Hydrogen (\%) & 5.61 & 5.80 & 5.52 & 5.57 & 5.53 & $5.61 \pm 0.11$ \\
\hline Nitrogen (\%) & 0.12 & 0.18 & 0.17 & 0.12 & 0.22 & $0.16 \pm 0.04$ \\
\hline Sulfur (\%) & 0.08 & 0.06 & 0.06 & 0.04 & 0.11 & $0.07 \pm 0.03$ \\
\hline Oxygen (\%) & 32.63 & 31.87 & 33.45 & 35.22 & 34.36 & $33.51 \pm 1.33$ \\
\hline PCN (MJ/kg) & 13.85 & 14.75 & 13.90 & 14.47 & 14.59 & $14.31 \pm 0.41$ \\
\hline
\end{tabular}

${ }^{*}$ Mean values for the five production lots \pm standard deviation.

3.2. Isokinetic Sampling and Analysis. Table 3 shows the results for the exhaust gases analysis. The excess air was very high, compared with the parameters indicated by Kuprianov et al. [20] and Sánchez et al. [19], who suggested percentages of excess air between $55 \%$ and $61 \%$. For this reason, a decrease in the combustion flame temperature was presented [11]. Among the different treatments evaluated, a reduction of temperature up to $50^{\circ} \mathrm{C}$ was found in the worst cases. Moreover, this additional air can be placed on the pans forming an isolating layer, affecting the heat exchange efficiency [21].

High excess air, in the case of lots 03 and 04, promoted lower carbon monoxide formation and a complete combustion phenomenon [22-24]. When the flame front is generated in a uniform way over bagasse (not shallow), the $\mathrm{CO}$ concentrations decrease due to oxidation of both volatile and carbonized materials [20]. The chimney gases temperature in experiments 03 and 04 were greater in comparison with productions 01,02 , and 05 , independent of the existence of an additional airflow that cooled the system. This fact enhances the heat transfer in the two mentioned cases, which is governed mainly by the mechanisms of radiation and forced convection.

According to Parra [25], the optimal gases velocity through the duct is equal to $4.5 \mathrm{~m} / \mathrm{s}$. In all experimental runs, the exhaust gases velocity was below of this value, which clearly indicates a chimney draft deficiency. Considering that the principal heat transfer mechanisms in the process are radiation and convection, the fluid slow circulation through the furnace affects its energy efficiency, which might increase with the redesign of combustion chamber and furnace [24].

3.3. Energy, Exergy, and Productivity. Table 4 shows the furnace performance indices. For obtaining these indices the mass, energy, and exergy balances established in this work were solved.

All performance indices, except energy efficiency index $(\% e)$, were found within the ranges established by Velásquez et al. [6], Velásquez et al. [16], and Sardeshpande et al. [24]. In the traditional furnace, an average efficiency of $12.73 \%$ was obtained, while the minimal efficiency reported by the cited authors was $28 \%$. Nevertheless, the references mentioned that this parameter can fall down to levels of $15 \%$. The low energy efficiency of the traditional furnace used in the current study can be attributed mainly to a wrong design of
TABLE 3: Results of the isokinetic testing for chimney gases.

\begin{tabular}{lccccc}
\hline Parameter & Lot 01 & Lot 02 & Lot 03 & Lot 04 & Lot 05 \\
\hline Excess air $(\%)$ & 129.920 & 216.210 & 173.710 & 288.130 & 127.930 \\
Temperature $\left({ }^{\circ} \mathrm{C}\right)$ & 434.650 & 473.470 & 451.410 & 465.850 & 417.390 \\
Velocity $(\mathrm{m} / \mathrm{s})$ & 2.700 & 2.900 & 2.700 & 3.270 & 2.800 \\
Humidity & 0.200 & 0.254 & 0.188 & 0.191 & 0.171 \\
$\left(\mathrm{~kg}_{\text {water }} / \mathrm{kg}_{\text {gh }}\right)$ & & & & & \\
$\% \mathrm{CO}$ & 5.000 & 2.600 & 1.200 & 0.700 & 1.900 \\
$\% \mathrm{CO}_{2}$ & 10.69 & 11.2 & 8.91 & 7.38 & 10 \\
$\% \mathrm{O}_{2}$ & 9.92 & 9.4 & 11.75 & 13.31 & 10.7 \\
$\% \mathrm{~N}_{2}$ & 74.129 & 76.614 & 78.039 & 78.529 & 77.234 \\
$\% \mathrm{NO}_{2}$ & 0.079 & 0.128 & 0.099 & 0.080 & 0.104 \\
$\% \mathrm{SO}_{2}$ & 0.183 & 0.057 & 0.001 & 0 & 0.062 \\
\hline
\end{tabular}

the combustion chamber and the heat transfer section $[6,21]$. Additionally, in the pilot traditional furnace, bagasse inlet was located on a lower level to that of the construction, limiting the uniform contact between the primary air and solid fuel (bagasse). Moreover, installed heat exchangers correspond to traditional semicylindrical pans, placed in parallel flow with respect to the combustion chamber, which makes that technology inefficient by its design. It is highlighted that this type of pan exhibits low overall heat transfer coefficients $[11,21]$.

Thermal loss through the furnace walls and chimney is other feature that aids to further decrease energy efficiency. Likewise, excess air in traditional furnace demands a complementary energy transfer to achieve its preheating. To guarantee drying, devolatilization, and oxidation during the combustion, a portion of bagasse energy available was used, denoting an irreversibility in the process, which reduced energy and exergy efficiencies in the traditional furnace $[11,19]$.

Despite having the lowest energy loss through the chimney, lots 01 and 05 also present a lower energy efficiency. The energy efficiency index, by definition, refers to the amount of heat lost with the gases leaving the line. In turn, this parameter is a function of the outgoing gases enthalpy and temperature [26]. In these two experimental cases, the lowest temperatures in the chimney were found; as a consequence, the energy efficiency in lots 01 and 05 were smaller. In addition, minor air excess during the combustion phenomena for these two experimental runs is the main cause of the few energy and exergy in the gases flow $[20,22]$. Also, the lowest excess air drives an incomplete combustion generating a high carbon monoxide concentration. The CO has lower enthalpy and thermal conductivity than the 
TABLE 4: Efficiency, productivity, and environmental indices for the traditional furnace.

\begin{tabular}{|c|c|c|c|c|c|c|}
\hline Indices & Lot 01 & Lot 02 & Lot 03 & Lot 04 & Lot 05 & Mean* \\
\hline$\% e$ & 11.450 & 13.846 & 14.008 & 12.794 & 11.533 & $12.726 \pm 1.091$ \\
\hline$\% e_{x}$ & 8.168 & 9.349 & 9.882 & 9.492 & 8.172 & $9.013 \pm 0.710$ \\
\hline$\% n$ & 61.924 & 75.898 & 73.757 & 91.152 & 58.736 & $72.293 \pm 11.507$ \\
\hline$R\left(\mathrm{~kg}_{\text {panela }} / \mathrm{kg}_{\text {bagasse }}\right)$ & 0.123 & 0.144 & 0.141 & 0.183 & 0.127 & $0.144 \pm 0.021$ \\
\hline$P\left(\mathrm{~kg}_{\text {panela }} / \mathrm{h}\right)$ & 7.098 & 8.223 & 6.753 & 7.356 & 7.821 & $7.450 \pm 0.520$ \\
\hline$B\left(\mathrm{~kg}_{\text {used bagasse }} / \mathrm{kg}_{\text {produced bagasse }}\right)$ & 1.443 & 1.270 & 1.149 & 1.063 & 1.366 & $1.258 \pm 0.139$ \\
\hline
\end{tabular}

The indices are $\% e$, energy efficiency, $\% e_{x}$, exergy efficiency, $\%$, index of energy loss through chimney, $R$, process yield, $P$, productivity, $B$, bagasse consumption. ${ }^{*}$ Mean values for the five production lots \pm standard deviation.

TABle 5: Technological alternatives for improving performance of traditional furnace.

\begin{tabular}{lc}
\hline Alternative/Technological improvement & Description \\
\hline Furnace operation in combined flow & $\begin{array}{c}\text { Fusion between the operation in counter- } \\
\text { current and parallel flow: juice clarification } \\
\text { near the chimney, evaporation above the } \\
\text { combustion chamber, and final } \\
\text { concentration of the product in the center } \\
\text { of the furnace. }\end{array}$
\end{tabular}

Use of improved combustion chambers: WARD-type chamber (CWC), developed by CIMPA (Colombia)

Combustion chamber with a drying ramp for wet bagasse. It has and independent entrance section, both for primary and secondary combustion air. (i) Increase of energy efficiency: Use of high amounts of heat for the evaporation of the water present in the juice (phase change)

(ii) Preservation of panela quality: The final product is protected from burning by the action of the maximum heat transfer in the concentration zone

(i) Reaction volume, three times higher than a traditional chamber

(ii) Allows wet bagasse and works with better excess air

(iii) Facilitates the air circulation and prevents the formation of high amounts of $\mathrm{CO}$

(iv) Range of temperatures up to $1200^{\circ} \mathrm{C}$

(i) Increase in the overall heat transfer coefficient and in the area/volume ratio Mainly, there are three significant improvements to traditional pans: adjusted semicylindrical, finned exchanger, and pyrotubular.

(ii) Improves the heat exchange between the combustion gases and the juice, achieving greater energy and exergy efficiencies

(i) Complete combustion. Reduction in

Utilization of blowers and valves, to ensure the suction of the necessary air to achieve complete combustion. Speed control of the combustion gases, in order to favor convective and radiant heat transfer.

Use of the chimney gases exergy for some operation in the process. For example, Energy integration the bagasse drying, the preheating of water or juice, among others, can be considered.

Use of steam in industrial operations

Replacement of the combustion chamber by a boiler that generates steam. This fluid is used as energy source in the heat exchangers. the appearance of gaseous species such as $\mathrm{CO}$ and $\mathrm{NO}_{x}$

(ii) Generation of desired temperatures (minimum of $500^{\circ} \mathrm{C}$ ).

(iii) Improvement of the energy, exergy and productive efficiency of the process

(i) Increase in the amount of energy used within the process

(ii) Presence of better energy, exergy and productive indices.

(iii) Operational costs reduction

(iv) Possibility of achieving fuel selfsufficiency in the traditional furnace

(i) Improvement in the heat transfer rate to the juice, as the steam is a cleaner fluid

(ii) Possibility of using natural gas as fuel in the boiler, making the process more convenient from the environmental point of view

(iii) Greater control and automation potential

(iv) Increase in the scale of production, also allowing the reduction of associated costs species obtained from complete combustion. This fact causes the heat transfer velocity reduction inside the furnace $[1,17]$. The highest $\mathrm{CO}$ concentration from incomplete combustion implies a physical exergy 30\% lower in comparison with the physical exergy when the $\mathrm{CO}_{2}$ formation predominates during the complete combustion. In this way, in an incomplete 
combustion, the exergy from the gases is lower, contributing to a less energy availability to be used for carrying out the heating and evaporation of sugarcane juice and panela $[16,19]$.

The average exergy efficiency for the experiments was $9.013 \pm 0.710$. Considering the values reported by Velásquez et al. [16], between $7.33 \%$ for an industrial process working with steam and $22.06 \%$ for an improved counter-current furnace (called GIPUN), it can be concluded that the exergetic performance of the traditional furnace was within standard values. For the same type of technology used in this research, cataloged as traditional and artisanal, the authors found an exergy efficiency of $10.94 \%$.

Because of low energy efficiency index found in the process assessment, none of the experiments presented a self-sustaining fuel $(B<1)$. This fact indicates a low utilization of biomass energy resource. In all experimental runs, exergy flow in exhaust gases with available potential was proved. Thus, exergy available can be performing subsequent heating operations using the hot chimney gases as the energy main source.

High standard deviation presented by the results was due to the minimal control maintained over the excess air and the combustion process, which directly affects the composition, temperature, and velocity of the chimney gases [6]. In cases of minor oxidizing flow (Lot 01, 02 and 05), it causes a biomass incomplete burn, a low heat transfer via convection, and a great emission of particulate material [20].

As can clearly be seen, the combustion phenomenon directly affects the energy, exergy, and productivity indices for the traditional panela-making furnace. The operation efficiency also depends on the way in which the heat transfer is carried out between the energy resource and the evaporated juice. Therefore, its behavior depends directly on the area and the heat transfer coefficient, as well as on the temperature difference between the gases and the pans $[11,16,21,22,24,26]$. According to Gutiérrez et al. [27], certain modifications can be made to the traditional process, in order to improve its performance from different the points of view. Table 5 presents some of these technological options.

\section{Conclusions}

The assessment of traditional furnace for manufacturing panela indicates that this technological configuration offers certain performance limitations and control over some operations, such as bagasse combustion, concentration of sugarcane juice, and noncentrifugal brown sugar obtaining. Among these problems, are highlighted the inappropriate location of the bagasse inlet, deficient furnace wall isolation, selection and use of inefficient pans (heat exchangers), high energy loss with exhaust gases, poor chimney draft, and the solid fuel uncontrolled burning. These last two aspects affect the traditional furnace performance, due to the fact that it gives way to the existence of an incomplete combustion phenomenon, generating low heat transfer rates through the juices, additionally producing carbon monoxide, particulate material, nitrous oxide and sulfur oxide. According to this, it can be concluded that the artisanal methods are inefficient from an energy and productivity point of view and generate a high environmental impact on the areas around the sugar mills.
The excess air is the most important factor that must be analyzed and controlled to enhance energy and productivity performances in the panela manufacturing process, since contact between the solid fuel and air allows using efficient advantage of the bagasse energy resource. Chimney gases composition depends on the factors temperature and velocity air through the furnace. The production process can be detained due to the loss through chimney draft and furnace duct clogging. In a direct manner, the excess air and chimney draft control the heat transfer rate by convection and radiation among the juices and fluids.

\section{Nomenclature}

$B: \quad$ Index for bagasse use and consumption

( $\left.\mathrm{kg}_{\text {used bagasse }} / \mathrm{kg}_{\text {produced bagasse }}\right)$

Cp $\mathrm{p}_{\mathrm{fl}}: \quad$ Flocculant specific heat $\left(\mathrm{kJ} / \mathrm{kg} \cdot{ }^{\circ} \mathrm{C}\right)$

$\mathrm{Cp}_{\mathrm{jc}}$ : $\quad$ Cane juice specific heat $\left(\mathrm{kJ} / \mathrm{kg} \cdot{ }^{\circ} \mathrm{C}\right)$

Cpp: $\quad$ Panela specific heat $\left(\mathrm{kJ} / \mathrm{kg} \cdot{ }^{\circ} \mathrm{C}\right)$

Cp $\mathrm{psch}$ : Specific heat of mud $\left(\mathrm{kJ} / \mathrm{kg} \cdot{ }^{\circ} \mathrm{C}\right)$

$\mathrm{Ex}_{\mathrm{ae}}$ : $\quad$ Exergy of evaporated water during the juice concentration $(\mathrm{kJ})$

$\mathrm{Ex}_{\mathrm{ap}}$ : $\quad$ Harnessed exergy $(\mathrm{kJ})$

$\mathrm{Ex}_{\mathrm{bh}}$ : Humid bagasse exergy $(\mathrm{kJ})$

$\mathrm{Ex}_{\mathrm{dp}}$ : $\quad$ Exergy destruction in the process $(\mathrm{kJ})$

$\mathrm{Ex}_{\mathrm{Fae}}$ : $\quad$ Evaporated water physical exergy $(\mathrm{kJ} / \mathrm{kg})$

$\mathrm{Ex}_{\mathrm{Fgh}}$ : Chimney gases physical exergy $(\mathrm{kJ} / \mathrm{kg})$

$\mathrm{Ex}_{\mathrm{Fp}}$ : Panela physical exergy $(\mathrm{kJ} / \mathrm{kg})$

$\mathrm{Ex}_{\mathrm{gh}}$ : Chimney gases exergy $(\mathrm{kJ})$

$\mathrm{Ex}_{\mathrm{jc}}$ : $\quad$ Sugarcane juice exergy $(\mathrm{kJ})$

Ex $_{\mathrm{p}}$ : Panela exergy $(\mathrm{kJ})$

$\mathrm{Ex}_{\mathrm{Qae}}$ : Water evaporated chemical exergy $(\mathrm{kJ} / \mathrm{kg})$

$\mathrm{Ex}_{\mathrm{Qbh}}$ : Humid bagasse chemical exergy $(\mathrm{kJ} / \mathrm{kg})$

$\mathrm{Ex}_{\mathrm{Qgh}}$ : Chimney gases chemical exergy $(\mathrm{kJ} / \mathrm{kg})$

$\mathrm{Ex}_{\mathrm{Qjc}} \mathrm{R} \quad$ Raw juice chemical exergy $(\mathrm{kJ} / \mathrm{kg})$

$\mathrm{Ex}_{\mathrm{QH} 2 \mathrm{O}}$ : Water chemical exergy $(\mathrm{kJ} / \mathrm{kg})$

$\mathrm{Ex}_{\mathrm{Qp}}$ : Panela chemical exergy $(\mathrm{kJ} / \mathrm{kg})$

$\mathrm{Ex}_{\mathrm{Qsucrose}}:$ Sucrose chemical exergy $(\mathrm{kJ} / \mathrm{kg})$

$E_{1}: \quad$ Cane bagasse energy $(\mathrm{kJ})$

$E_{2}: \quad$ Air energy $(\mathrm{kJ})$

$E_{3}: \quad$ Cane juice energy $(\mathrm{kJ})$

$E_{4}$ : $\quad$ Energy of solid contaminants presents in cane juice $(\mathrm{kJ})$

$E_{5}: \quad$ Clarification extract energy $(\mathrm{kJ})$

$E_{6}$ : $\quad$ Panela energy $(\mathrm{kJ})$

$E_{7}: \quad$ Mud energy $(\mathrm{kJ})$

$E_{8}$ : $\quad$ Energy of steam removed during concentration $(\mathrm{kJ})$

$E_{9}$ : $\quad$ Chimney gases energy $(\mathrm{kJ})$

$E_{10}$ : Other energy losses (kJ)

$h$ : $\quad$ Mass enthalpy $(\mathrm{kJ} / \mathrm{kg})$

$h_{\text {mae }}$ : $\quad$ Molar enthalpy of water evaporated from juices $(\mathrm{kJ} / \mathrm{kmol})$

$h_{\mathrm{mgh}}: \quad$ Molar enthalpy of humid chimney gases $(\mathrm{kJ} / \mathrm{kmol})$

$H_{\mathrm{Y}}: \quad$ Enthalpy of humid ambient air $\left(\mathrm{kJ} / \mathrm{kg}_{\mathrm{as}}\right)$

$h_{\mathrm{o}}$ : $\quad$ Mass enthalpy evaluated at room temperature $(\mathrm{kJ} / \mathrm{kg})$

$m_{\text {aa }}$ Water mass, with the combustion air (kg) 


\begin{tabular}{|c|c|}
\hline$m_{\mathrm{ab}}:$ & Water mass contained in the bagasse $(\mathrm{kg})$ \\
\hline$m_{\mathrm{ae}}:$ & Evaporated water mass $(\mathrm{kg})$ \\
\hline$M_{\mathrm{ae}}:$ & Molecular weight of evaporated water $(\mathrm{kg} / \mathrm{kmol})$ \\
\hline$m_{\mathrm{as}}:$ & Dried air mass used in combustion $(\mathrm{kg})$ \\
\hline$m_{\mathrm{at}}:$ & $\begin{array}{l}\text { Steam mass leaving the system with the chimney } \\
\text { gases }(\mathrm{kg})\end{array}$ \\
\hline$m_{\mathrm{bh}}:$ & Humid bagasse mass (kg) \\
\hline$m_{\mathrm{bs}}:$ & Dried bagasse mass $(\mathrm{kg})$ \\
\hline$m_{\mathrm{ch}}:$ & Removed mud mass (kg) \\
\hline$m_{\mathrm{fl}}:$ & Mass extract flocculant $(\mathrm{kg})$ \\
\hline$M_{\mathrm{gh}}$ & $\begin{array}{l}\text { Molecular weight of humid gases in chimney } \\
(\mathrm{kg} / \mathrm{kmol})\end{array}$ \\
\hline$m_{\mathrm{gh}}:$ & Humid gases mass in chimney $(\mathrm{kg})$ \\
\hline$m_{\mathrm{gs}}:$ & Dry gases mass through chimney $(\mathrm{kg})$ \\
\hline$m_{\mathrm{jc}}:$ & Cane juice mass $(\mathrm{kg})$ \\
\hline$m_{\mathrm{lch}}:$ & Juice mass remaining from mud $(\mathrm{kg})$ \\
\hline$m_{\mathrm{mp}}:$ & Particulate material $(\mathrm{kg})$ \\
\hline$m_{\mathrm{p}}:$ & Panela obtained at the end of process $(\mathrm{kg})$ \\
\hline$m_{\mathrm{r}}:$ & Unburned residues $(\mathrm{kg})$ \\
\hline$m_{\mathrm{sch}}:$ & Mass of solids presents in mud (kg) \\
\hline$P:$ & Furnace productivity $\left(\mathrm{kg}_{\text {panela }} / \mathrm{h}\right)$ \\
\hline PCN: & Lower calorific value of the bagasse $(\mathrm{MJ} / \mathrm{kg})$ \\
\hline$R:$ & $\begin{array}{l}\text { Universal constant of ideal gases } \\
\left(8.3140 \mathrm{kPa} \cdot \mathrm{m}^{3} / \mathrm{kmol} \cdot \mathrm{K}\right)\end{array}$ \\
\hline$R:$ & Yield ( $\left.\mathrm{kg}_{\text {panela }} / \mathrm{kg}_{\text {bagasse }}\right)$ \\
\hline$s:$ & Entropy $(\mathrm{kJ} / \mathrm{kg} \cdot \mathrm{K})$ \\
\hline$s_{\mathrm{o}}:$ & $\begin{array}{l}\text { Entropy evaluated at room temperature } \\
(\mathrm{kJ} / \mathrm{kg} \cdot \mathrm{K})\end{array}$ \\
\hline$T_{\mathrm{cl}}:$ & $\begin{array}{l}\text { Temperature at cane juice clarification }\left({ }^{\circ} \mathrm{C} \text { or } \mathrm{K} \text {, }\right. \\
\text { according to equation) }\end{array}$ \\
\hline$T_{\mathrm{fl}}:$ & $\begin{array}{l}\text { Flocculant extract temperature }\left({ }^{\circ} \mathrm{C} \text { or } \mathrm{K} \text {, }\right. \\
\text { according to equation) }\end{array}$ \\
\hline$T_{\mathrm{jc}}:$ & $\begin{array}{l}\text { Cane juice temperature }\left({ }^{\circ} \mathrm{C} \text { or } \mathrm{K} \text {, according to }\right. \\
\text { equation) }\end{array}$ \\
\hline$t_{\text {production }}:$ & Total production time $(\mathrm{s})$ \\
\hline$T_{\text {point }}:$ & $\begin{array}{l}\text { Temperature of Panela-making point }\left({ }^{\circ} \mathrm{C} \text { or } \mathrm{K} \text {, }\right. \\
\text { according to equation) }\end{array}$ \\
\hline$T_{\mathrm{sc}}:$ & $\begin{array}{l}\text { Temperature of contaminant solids in cane } \\
\text { juice }\left({ }^{\circ} \mathrm{C} \text { or } \mathrm{K} \text {, according to equation) }\right.\end{array}$ \\
\hline$T_{0}:$ & Reference temperature $(\mathrm{K})$ \\
\hline$T_{\mathrm{o}}:$ & Room temperature $(\mathrm{K})$ \\
\hline$w:$ & $\begin{array}{l}\text { Raw bagasse mass fraction of humidity } \\
\left(\mathrm{kg}_{\mathrm{H}_{2} \mathrm{O}} / \mathrm{kg}\right)\end{array}$ \\
\hline$w_{\mathrm{gh}}:$ & $\begin{array}{l}\text { Mass fraction of humidity in chimney gases } \\
\left(\mathrm{kg}_{\mathrm{H}_{2} \mathrm{O}} / \mathrm{kg}\right)\end{array}$ \\
\hline$x:$ & Mass fraction \\
\hline$\% e:$ & Energy efficiency \\
\hline \%ex: & Exergy efficiency \\
\hline$\% n:$ & Energy loss via furnace chimney \\
\hline$\gamma_{\mathrm{H}_{2} \mathrm{O}}$ & Molar fraction of water \\
\hline$\gamma_{i}:$ & Molar fraction of material $i$ \\
\hline$\gamma_{j}:$ & Molar fraction of material $j$ \\
\hline$\varphi:$ & Physical exergy for a gas flow (kJ/kg). \\
\hline
\end{tabular}

\section{Data Availability}

The data used to support the findings of this study are available from the corresponding author upon request.

\section{Conflicts of Interest}

The authors declare that there are no conflicts of interest regarding the publication of this paper.

\section{Acknowledgments}

Thanks are due to Universidad de Caldas and the project "Implementation of the Research, Innovation and Technology Center for the Panela Sector of the Department of Caldas, BEKDAU Center," financed by the General System of Royalties (SGR).

\section{References}

[1] G. N. Tiwari, S. Kumar, and O. Prakash, "Study of heat and mass transfer from sugarcane juice for evaporation," Desalination, vol. 159, no. 1, pp. 81-96, 2003.

[2] J. Singh, S. Solomon, and D. Kumar, "Manufacturing jaggery, a product of sugarcane, as health food," Agrotechnology, vol. 11, no. S11, pp. 1-3, 2013.

[3] Revista Dinero, El negocio de la panela crece y se derrite a la vez $[O L], 2014$, http://www.dinero.com/empresas/articulo/ balance-del-sector-panelero-colombia-2014/202561.

[4] Periódico El País, Campaña para consumo de panela recibió premio internacional en Argentina [OL], 2015, http://www.elpais. com.co/elpais/economia/noticias/campana-para-consumopanela-recibio-premio-internacional-argentina.

[5] H. R. García, L. C. Albarracín, A Toscano et al., Guía Tecnológica para el Manejo Integral del Sistema Productivo de Caña Panelera, Corpoica, Bogotá, Colombia, 2007.

[6] H. I. Velásquez, F. Chejne, and A. F. Agudelo, "Diagnóstico energético de los procesos productivos de la panela en Colombia," Revista Facultad Nacional de Agronomía Medellín, vol. 57, no. 2, pp. 1-15, 2004.

[7] P. V. K. Jagannadha Rao, M. Das, and S. K. Sas, "Changes in physical and thermo-physical properties of sugarcane, palmyrapalm and date-palm juices at different concentration of sugar," Journal of Food Engineering, vol. 90, no. 4, pp. 559-566, 2009.

[8] P. Laksameethanasan, N. Somla, S. Janprem et al., "Clarification of sugarcane juice for syrup production," Procedia Engineering, vol. 32, pp. 141-147, 2012.

[9] EPA United States Environmental Protection Agency, Code of Federal Regulations, Title 40, Protection of Environment, Part 60 (Appendix), US EPA, Washington, DC, USA, 1991.

[10] S. Arias, A. M. Ceballos, and L. F. Gutiérrez, "Determinación experimental de propiedades térmicas y físicas para jugo de caña, miel y panela," Vitae, vol. 23, no. 1, pp. 145-148, 2016.

[11] J. Y. Shiralkar, S. K. Kancharla, N. G. Shah et al., "Energy improvements in jaggery making process," Energy for Sustainable Development, vol. 18, pp. 36-48, 2014.

[12] C. J. Geankoplis, Transport Processes and Separation Process Principles (Includes Unit Operations), Prentice Hall, Upper Saddle River, NJ, USA, 4th edition, 2003.

[13] J. D. Seader, E. J. Henley, and D. K. Roper, Separation Process Principles. Chemical and Biochemical Operations, John Wiley and Sons Inc., New York, NY, USA, 3rd edition, 2010.

[14] C. F. Montoya and P. A. Giraldo, Propuesta de Diseño de Planta de Procesamiento de Caña para la Elaboración de Panela en Yolombo-Antioquia, Universidad Nacional de Colombia, Medellín, Colombia, 2009.

[15] J. Coutinho, G. Kontogeorgis, and E. Stenby, "Binary interaction parameters for nonpolar systems with cubic 
equations of state: a theoretical approach. $\mathrm{CO}_{2} /$ hydrocarbons using SRK equation of state," Fluid Phase Equilibria, vol. 102, no. 1, pp. 31-60, 1994.

[16] H. I. Velásquez, F. Chejne, and A. F. Agudelo, "Diagnóstico exergético de los procesos productivos de panela en Colombia," Energética, vol. 35, pp. 15-22, 2006.

[17] Y. A. Cengel and M. A. Boles, Thermodynamics: an Engineering Approach, McGraw-Hill College, Boston, MA, USA, 5th edition, 2006.

[18] T. J. Kotas, The Exergy Method of Thermal Plant Analysis, Paragon Publishing, London, UK, 2012.

[19] Z. Sánchez, H. R. García, and O. A. Mendieta, "Efecto del precalentamiento del aire primario y la humedad del bagazo de caña de azúcar durante la combustión en lecho fijo," Corpoica Ciencia y Tecnología Agropecuaria, vol. 14, no. 1, pp. 5-16, 2013.

[20] V. I. Kuprianov, W. Permchart, and K. Janvijitsakula, "Fluidized bed combustion of pre-dried thai bagasse," Fuel Processing Technology, vol. 86, no. 8, pp. 849-860, 2005.

[21] S. I. Anwar, "Fuel and energy saving in open pan furnace used in jaggery making through modified juice boiling/ concentrating pans," Energy Conversion and Management, vol. 51, no. 2, pp. 360-364, 2010.

[22] M. Baratieri, P. Baggio, L. Fiori et al., "Biomass as an energy source: thermodynamic constraints on the performance of the conversion process," Bioresource Technology, vol. 99, no. 15, pp. 7063-7073, 2008.

[23] L. Wang, C. L. Weller, D. D. Jones et al., "Contemporary issues in thermal gasification of biomass and its application to electricity and fuel production," Biomass and Bioenergy, vol. 32, no. 7, pp. 573-581, 2008.

[24] V. R. Sardeshpande, D. J. Shendage, and I. R. Pillai, "Thermal performance evaluation of a four pan jaggery processing furnace for improvement in energy optimization," Energy, vol. 35, no. 12, pp. 4740-4747, 2010.

[25] J. A. Parra, "Análisis térmico de una paila panelera," Revista Ingenio Libre, vol. 5, pp. 44-50, 2006.

[26] J. A. Osorio, H. J. Ciro, and A. Espinosa, "Evaluación térmica y validación de un modelo por métodos computacionales para la hornilla panelera GP150," Dyna, vol. 77, no. 162, pp. 237-247, 2010.

[27] L. F. Gutiérrez, S. Arias, and A. M. Ceballos, "Advances in traditional production of panela in Colombia: analysis of technological improvements and alternatives," Ingeniería y competitividad, vol. 20, no. 1, pp. 107-123, 2018. 


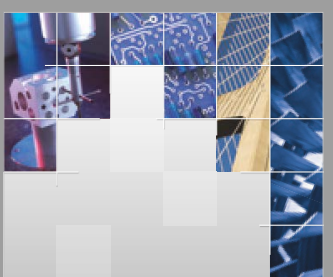

\section{Enfincering}
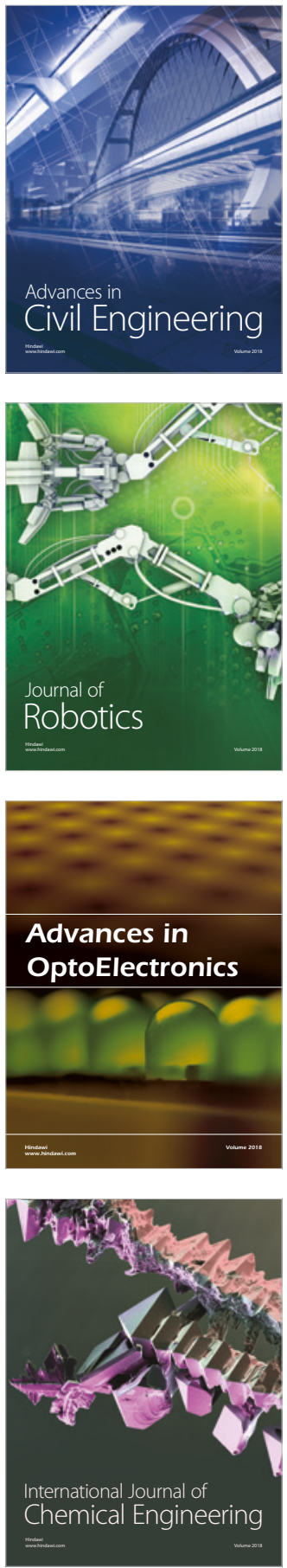

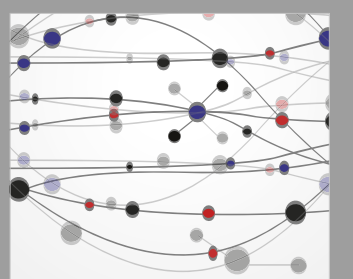

\section{Rotating \\ Machinery}

The Scientific World Journal

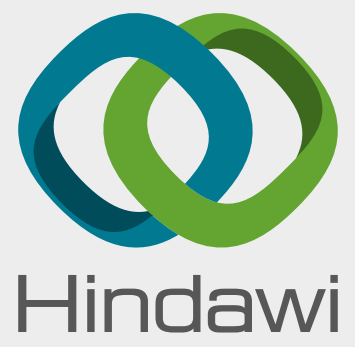

Submit your manuscripts at

www.hindawi.com

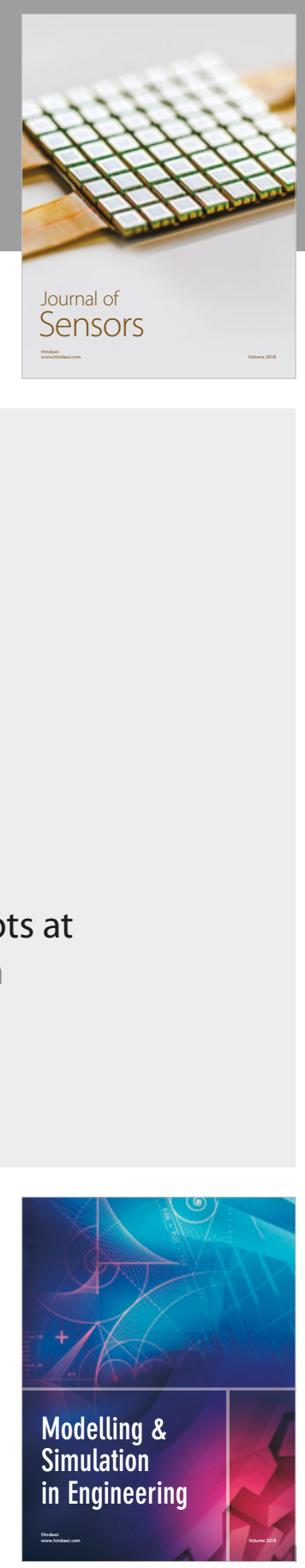

\section{Advances \\ Multimedia}
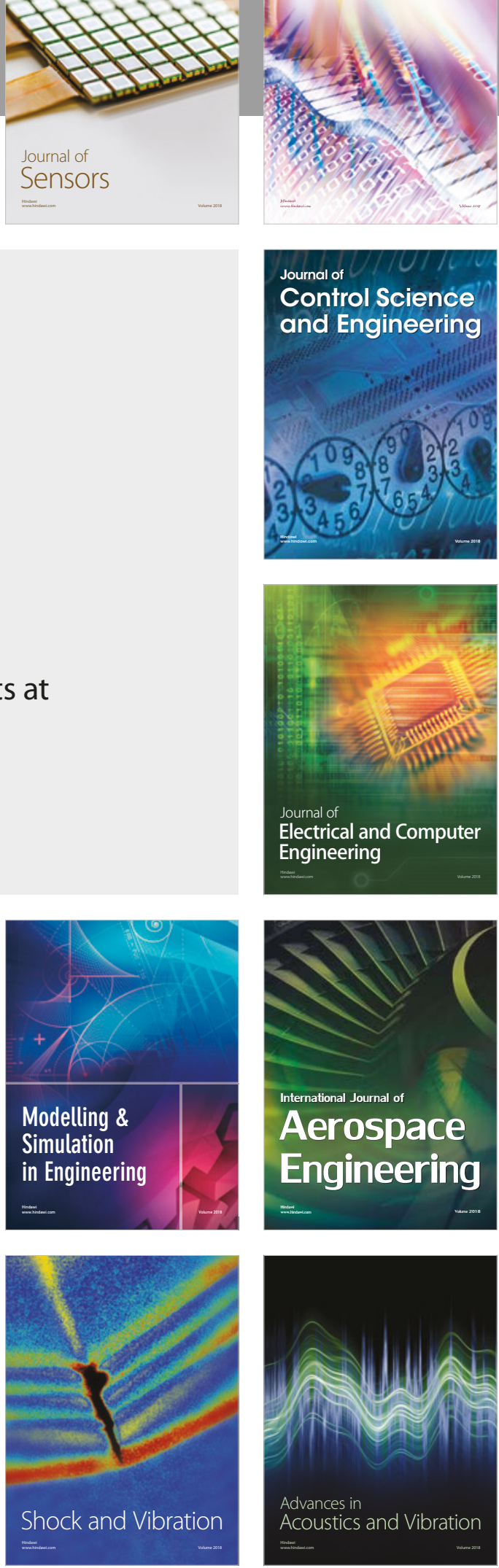